\title{
Chemical Composition and Antimicrobial Activity of Fraxinus excelsior L. Seeds Essential Oil
}

\author{
Mohaddese Mahboubi ${ }^{1,}$, , Elaheh Mahdizadeh ${ }^{1}$ and Rezvan Heidary Tabar ${ }^{1}$ \\ ${ }^{1}$ Department of Microbiology, Medicinal Plant, Research Center of Barij, Kashan, Iran \\ "Corresponding author: Department of Microbiology, Medicinal Plant, Research Center of Barij, Kashan, Iran. Tel/Fax: +98-8644465187, Email: mahboubi1357@yahoo.com
}

Received 2017 August 30; Revised 2018 March 04; Accepted 2018 August 26.

\begin{abstract}
Background: Fraxinus excelsior L. has been traditionally used as a diuretic, carminative and gallstone crusher. The antimicrobial activity of Fraxinus excelsior L. leaves and bark extract has been confirmed against bacteria and fungi.

Objectives: The aim of this study was to evaluate the chemical composition and antimicrobial activity of Fraxinus excelsior L. seed essential oil.

Methods: Chemical composition of F. excelsior was analyzed by gas chromatography (GC) and gas chromatography-mass spectrometry (GC-MS), and its antimicrobial activity was evaluated by disc diffusion and micro broth dilution assays.

Results: Overall, 53 components were identified in the essential oil, which constitute $99.98 \%$ of total oil composition. Carotol (16.25\%), $\alpha$-cadinol (13.33\%), $\delta$-cadinene (12.4\%), bicyclogermacrene (10.34\%), $\alpha$-muurolol (9.69\%), and E-caryophyllene (5.9\%) were the main components of the essential oil. The essential oil showed the best activity against the standard strain of Staphylococcus aureus, while Pseudomonas aeruginosa and Candida albicans had less sensitivity to it. The mean minimum inhibitory concentration (MIC) and minimum bactericidal concentration (MBC) values of the essential oil against clinical isolates of S. aureus were $0.162 \pm 0.024$ and $0.31 \pm 0.067 \mu \mathrm{L} / \mathrm{mL}$, respectively.
\end{abstract}

Conclusions: Therefore, the essential oil can be a suitable candidate for further studies against staphylococcal infections.

Keywords: Fraxinus excelsior, Seed, Essential Oil, Staphylococcus aureus, Carotol

\section{Background}

Fraxinus excelsior L., a member of Oleaceae family, has been traditionally used as a gallstone crusher and carminative (1). FraxiPure $^{\mathrm{TM}}$ is a safe natural extract obtained from F. excelsior that was shown to reduce glycaemia in animal models and human clinical trials (2). Hippocrates used F. excelsior leaves and bark as diuretics and for the treatment of rheumatoid, fever, wound, diarrhea, and dysentery (3). Coumarins (e.g., esculin and fraxin), secoiridoids, phenylethanoid glycosides (i.e., verbascoside, salidroside, calceolarioside A, B, lugrandoside, isolugrandoside, and isoacteoside), lignans, flavonoids, phenolic compounds (e.g., p-hydroxybenzoic acid, protocatechuic acid, vanillic acid, synergic acid, 2, 4-dihydroxybenzoic acid, and gallic acid), sterols, and triterpenes were the isolated chemical components of $F$. excelsior (3).

The ethyl ether fraction of $F$. excelsior bark ethanolic extract has inhibitory effects against Bacillus subtilis (4). F. excelsior leaves extract has antifungal activity against Gloeosporum limetticola and Alternaria tennis (5). F. excelsior leaves aqueous extract has been found to suppress the growth of Candida albicans, while its bark aqueous ex- tract showed antimicrobial activity against Staphylococcus aureus and Proteus mirabilis. The antibacterial (6), antiinflammatory (7), anti-oxidant (6), diuretic (3), antihypertensive (8), analgesic, antipyretic (9), and hypoglycemic activity (10-12) of $F$. excelsior extract have also been confirmed. Although the antimicrobial activity of F. excelsior leaves and bark extracts were confirmed against bacteria and fungi, there is a scarcity of studies evaluating the chemical composition and antimicrobial activity of F. excelsior seed essential oil.

\section{Objectives}

The aim of this study was to evaluate the chemical composition and antimicrobial activity of $F$. excelsior seed essential oil.

\section{Methods}

\subsection{Plant Materials, Essential Oil Extraction and Analysis}

F. excelsior seeds were collected from the research garden of BarijEssence Pharmaceutical Company, Kashan, 
Iran. The plant materials were identified and authenticated. Then, $100 \mathrm{~g}$ of seed was hydrodistilled by water in Clevenger type apparatus for $4 \mathrm{~h}$. The essential oil was gathered and subjected to identification by gas chromatography (GC) and gas chromatography-mass spectrometry (GC-MS) analyses. The GC and GC-MS analyses were performed by Shahid Beheshti Medicinal Plant Research Center. The GC analysis was carried out on Trace MS (Thermo Quest- Finnigan, China) using capillary column of DB-5 (30 $\mathrm{m} \times 0.25 \mathrm{~mm}$; film thickness, $0.25 \mu \mathrm{m})$, the oven temperature program was initiated at $60^{\circ} \mathrm{C}$ for $1 \mathrm{~min}$, then increased up to $250^{\circ} \mathrm{C}$ at a rate of $3^{\circ} \mathrm{C} / \mathrm{min}$, and held isothermal for $10 \mathrm{~min}$.

The injector and detector temperatures were fixed at $230^{\circ} \mathrm{C}$ and $250^{\circ} \mathrm{C}$, respectively. GC-MS analysis was performed using Trace MS (Thermo Quest-Finnigan) equipped with 5973 network mass selective detector system. The carrier gas was helium used at a flow rate of $1.1 \mathrm{~mL} / \mathrm{min}$ with a split ratio of column sample injection equal to 1/100. Oven temperature program was set the same as GC mentioned above. The results were interpreted and reported according to comparison with retention indices (RI) relative to homologous series of n-alkanes and using libraries of Wiley 275.L and Wiley $7 n .1$ and through comparison of the fragmentation pattern of the mass spectra with data published in the literature (13).

\subsection{Microbial Strains}

The microbial strains used in this study included Staphylococcus aureus ATCC 6538, Pseudomonas aeruginosa ATCC 9027, and Candida albicans ATCC 10231. Eleven clinical strains of $S$. aureus were used for further evaluations. These strains were isolated from patients with staphylococcal infections. The microbial strains were cultured on Soybean Casein Digest Agar and incubated at $37^{\circ} \mathrm{C}$ in aerobic conditions for 24 - $72 \mathrm{~h}$. Sabouraud Dextrose Agar was used for Candida albicans. One or two colonies of each strain were suspended in sterilized buffer with $\mathrm{pH} 7.2$ and its turbidity was adjusted to 0.5 McFarland by spectrophotometric method $\left(1 \times 10^{8} \mathrm{CFU} / \mathrm{mL}\right.$ for bacteria and $1 \times 10^{6} \mathrm{CFU} / \mathrm{mL}$ for C. albicans).

\subsection{Antimicrobial Evaluations of Essential Oil}

The antimicrobial activity screening of $F$. excelsior essential oil against microbial strains was screened by two different methods including disc diffusion method and micro-broth dilution assay.

In the disc diffusion method, the adjusted microbial strains to 0.5 McFarland were cultured on Muller Hinton Agar or Sabouraud Dextrose Agar by swab, and the discs containing $2.5,5$, and $7.5 \mu \mathrm{L}$ of essential oil dissolved in dimethyl sulfoxide were put on culture media. The plates were incubated at $37^{\circ} \mathrm{C}$ in aerobic conditions for $24 \mathrm{~h}$. After incubation, the inhibition zone diameters were measured in millimeter and reported. All the experiments were performed in triplicate and reported as mean \pm standard deviation (SD). Vancomycin (30 $\mu \mathrm{g} /$ disc), gentamicin (10 $\mu \mathrm{g} /$ disc), and amphotericin B (10 $\mu \mathrm{g} /$ disc) (Rosco Diagnostica) were used as positive controls.

In micro-broth dilution assay, the microbial suspensions were diluted in $1 / 200$. The colony-forming units (CFUs) were $1 \times 10^{6}$ and $1 \times 10^{4} \mathrm{CFU} / \mathrm{mL}$ for bacteria and yeasts, respectively. The essential oil was dissolved in dimethyl sulfoxide and diluted in Muller Hinton broth or RPMI 1640 (Roswell Park Memorial Institute medium) within the range of $0.03-16 \mu \mathrm{L} / \mathrm{mL}$ of essential oil. Then, $100 \mu \mathrm{L}$ of each dilution was mixed with $100 \mu \mathrm{L}$ of diluted microbial strains in 96-well microtiter plates. The plates were incubated in the above conditions. The lowest concentration of essential oil that inhibits the microbial strains in wells is the minimum inhibitory concentration (MIC) and the lowest concentration of essential oil that inhibits the growth of microbial strains on solid media is minimal lethal concentration (MLC) (14).

\section{Results}

\subsection{Chemical Composition of F. excelsior Seed Essential Oil}

GC-MS analysis of F. excelsior seed essential oil showed the presence of 53 components, which account for $99.98 \%$ of total oil composition. Carotol (16.25\%), $\alpha$-cadinol (13.33\%), $\delta$-cadinene (12.4\%), bicyclogermacrene (10.34\%), $\alpha$ muurolol (9.69\%), E-caryophyllene (5.9\%), and $\beta$-elemene (3.75\%) were the main components of essential oil, followed by $\beta$-cadinene (3.18\%), $\delta$-cadinol (2.99\%), and spathulenol (2.54\%), respectively (Table 1 ).

\subsection{The Antimicrobial Activity of F. excelsior Seed Essential Oil}

The results of the first antimicrobial screening showed that among Gram-positive and Gram-negative bacteria and yeasts, the most sensitive microorganism was the Grampositive bacterium of $S$. aureus with inhibition zone diameters of $9.7-11 \mathrm{~mm}$ in the presence of $2.5-7.5 \mu \mathrm{L} /$ disc $F$. excelsior essential oil and the MIC and MLC values of 0.06 and $0.108 \mu \mathrm{L} / \mathrm{mL}$, respectively (Table 2 ).

Due to acceptable antibacterial activity of $F$. excelsior essential oil against $S$. aureus, the antibacterial activity of F. excelsior essential oil was evaluated against clinical isolates of S. aureus. The results of screening showed that the inhibition zone diameter of essential oil increased dosedependently and this inhibition zone diameter was lower than that of vancomycin. The mean inhibition zone diameter for $7.5 \mu \mathrm{L}$ of essential oil against clinical isolates of $S$. 


\begin{tabular}{|c|c|c|c|}
\hline Row & Compounds & Retention Index & Percent \\
\hline 1 & $\alpha$-pinene & 933 & 0.07 \\
\hline 2 & Sabinene & 973 & 0.07 \\
\hline 3 & $\beta$-pinene & 978 & 0.23 \\
\hline 4 & P-cymene & 1025 & 0.16 \\
\hline 5 & Limonene & 1029 & 0.96 \\
\hline 6 & 1, 8-cineole & 1032 & 0.11 \\
\hline 7 & Linalool & 1100 & 0.14 \\
\hline 8 & Menthol & 1175 & 0.02 \\
\hline 9 & Terpinen-4-ol & 1180 & 0.06 \\
\hline 10 & $\alpha$-terpineol & 1194 & 0.06 \\
\hline 11 & $\beta$-citronellol & 1231 & 0.06 \\
\hline 12 & Z-citral & 1242 & 0.04 \\
\hline 13 & Geraniol & 1257 & 0.22 \\
\hline 14 & E-citral & 1272 & 0.06 \\
\hline 15 & Bicycloelemene & 1340 & 0.49 \\
\hline 16 & $\alpha$-cubebene & 1353 & 0.12 \\
\hline 17 & Neryl acetate & 1366 & 0.01 \\
\hline 18 & Cyclosativen & 1369 & 0.03 \\
\hline 19 & $\alpha$-copaene & 1379 & 0.27 \\
\hline 20 & Geranyl acetate & 1385 & 0.02 \\
\hline 21 & $\beta$-elemene & 1397 & 3.75 \\
\hline 22 & Junipene & 1400 & 0.03 \\
\hline 23 & $\alpha$-gurjunene & 1414 & 0.74 \\
\hline 24 & E-caryophyllene & 1426 & 5.91 \\
\hline 25 & Calarene & 1433 & 0.12 \\
\hline 26 & Trans- $\alpha$-bergamotene & 1439 & 0.21 \\
\hline 27 & Aromadendrene & 1443 & 0.18 \\
\hline 28 & $\alpha$-humulene & 1459 & 1.19 \\
\hline 29 & Alloaromadendrene & 1466 & 1.01 \\
\hline 30 & $\gamma$-muurolene & 1482 & 1.19 \\
\hline 31 & Germacrene D & 1486 & 1.18 \\
\hline 32 & Bicyclogermacrene & 1506 & 10.34 \\
\hline 33 & $\alpha$-muurolene & 1506 & 1.92 \\
\hline 34 & $\beta$-bisabolene & 1513 & 0.39 \\
\hline 35 & $\beta$-cadinene & 1521 & 3.18 \\
\hline 36 & D-nerolidol & 1526 & 1.32 \\
\hline 37 & $\delta$-cadinene & 1533 & 12.41 \\
\hline 38 & $\beta$-elemol & 1555 & 2.15 \\
\hline 39 & $\beta$-calacorene & 1569 & 0.22 \\
\hline 40 & Palustrol & 1574 & 0.25 \\
\hline 41 & $\delta$-cadinol & 1584 & 2.99 \\
\hline 42 & Spathulenol & 1586 & 2.54 \\
\hline 43 & Globulol & 1591 & 1.11 \\
\hline 44 & Viridiflorol & 1598 & 0.42 \\
\hline 45 & Ledol & 1610 & 0.65 \\
\hline 46 & 1,10-di-epi-cubenol & 1621 & 0.27 \\
\hline 47 & 1, epi-cubenol & 1634 & 0.65 \\
\hline 48 & $\gamma$-eudesmol & 1638 & 0.36 \\
\hline 49 & $\alpha$-muurolol & 1651 & 9.69 \\
\hline 50 & $\alpha$-cadinol & 1667 & 13.33 \\
\hline 51 & Carotol & 1705 & 16.25 \\
\hline 52 & $(2 \mathrm{Z}, 6 \mathrm{E})$-farnesol & 1727 & 0.47 \\
\hline 53 & Oplopanone & 1746 & 0.36 \\
\hline
\end{tabular}

aureus was $9.3 \pm 0.19 \mathrm{~mm}$ versus $19.6 \pm 0.19$ for $30 \mu \mathrm{g}$ of vancomycin.

MIC values of essential oil against clinical isolates of S. aureus were within the range of $0.05-0.21 \mu \mathrm{L} / \mathrm{mL}$ with the mean of $0.162 \pm 0.024 \mu \mathrm{L} / \mathrm{mL}$. These values were 0.25 - 1 and $0.58 \pm 0.27 \mu \mathrm{g} / \mathrm{mL}$ for vancomycin. The MBC values of essential oil and its mean were $0.125-1$ and $0.31 \pm$ $0.067 \mu \mathrm{L} / \mathrm{mL}$, respectively. The corresponding values for vancomycin were $0.5-2$ and $1.04 \pm 0.49 \mu \mathrm{g} / \mathrm{mL}$ (Table 3 ).

\section{Discussion}

F. excelsior seed, leaves, and bark extract have been traditionally used for the treatment of different ailments in various parts of the world. In this study, we extracted $F$. excelsior seed essential oil for the first time. The inhibition zone diameter of $F$. excelsior seed essential oil against clinical isolates of $S$. aureus was not correlated with the results of micro broth dilution assay. This phenomenon is related to the molecular weight of essential oil components, solubility in agar media, and vaporization of essential oil; therefore, the disc diffusion method was not a suitable assay for evaluating the efficacy of the essential oil.

Carotol, a squiterpenoid compound, is the main component of carrot seed oil (15), carotol, and caryophyllene as the main components of carrot seed oil inhibit the radial growth of Alternaria alternata by 65\% (16), Staphylococcus aureus, and Bacillus subtilis (17). Therefore, the antimicrobial activity of $F$. excelsior seed essential oil can be related to its contents such as carotol and caryophyllene. The antimicrobial activity of caryophyllene was confirmed against S. aureus, S. typhimurium, E. coli, Enterococcus faecalis, Aspergillus niger, Fusarium solari, Aspergillus fumigatus, and Aspergillus parasiticum (18).

S. aureus as an important pathogen in nosocomial infections showed sensitivity to F. excelsior seed essential oil; therefore, it can be concluded that the essential oil can be a suitable choice for further studies to combat S. aureus infections.

\section{Footnotes}

Authors' Contribution: Elaheh Mahdizadeh and Rezvan Heidary Tabar performed the examinations; Mohaddese Mahboubi supervised the study and wrote the manuscript. Conflict of Interests: There is no conflict of interest. Funding/Support: Funding for this work was provided by Medicinal Plants Research Center of Barij, Kashan, Iran. 


\begin{tabular}{|c|c|c|c|c|c|c|c|c|}
\hline & \multicolumn{5}{|c|}{ Disc Diffusion Method $^{\mathrm{a}}$} & \multicolumn{3}{|c|}{ Broth Dilution } \\
\hline & \multicolumn{4}{|c|}{ Essential Oil ( $\mu \mathbf{L} /$ disc $)$} & \multirow{2}{*}{\multicolumn{2}{|c|}{$\begin{array}{l}\text { Antibiotics } \\
(\mu \mathrm{g} / \text { disc })\end{array}$}} & \multicolumn{2}{|c|}{ Essential Oil $(\mu \mathbf{L} / \mathbf{m L})$} \\
\hline & \multicolumn{2}{|c|}{2.5} & 5 & 7.5 & & & MIC & MLC \\
\hline S. aureus & \multicolumn{2}{|c|}{$9.67 \pm 0.49$} & $9.82 \pm 0.66$ & $10.7 \pm 0.46$ & \multicolumn{2}{|c|}{$21.6 \pm 0.6^{\mathrm{A}}$} & 0.06 & 0.108 \\
\hline P. aeruginosa & \multicolumn{2}{|c|}{-} & - & - & \multicolumn{2}{|c|}{$19 \pm 0.0^{\mathrm{B}}$} & 8 & 8 \\
\hline C.albicans & \multicolumn{2}{|c|}{-} & - & - & \multicolumn{2}{|c|}{$21 \pm 0.0^{\mathrm{C}}$} & 7 & 7 \\
\hline \multicolumn{9}{|c|}{ a In disc diffusin method: A, vancomycin 30; B, gentamicin 10; C, amphotericin B 10.} \\
\hline & \multicolumn{4}{|c|}{ Disc Diffusion Method } & \multicolumn{4}{|c|}{ Microbroth Dilution } \\
\hline & \multicolumn{3}{|c|}{ Essential Oil $(\mu \mathrm{L} /$ disc $)$} & $\operatorname{Van}(\mu \mathbf{g} /$ disc $)$ & \multicolumn{2}{|c|}{ Essential Oil $(\mu \mathbf{L} / \mathbf{m L})$} & \multicolumn{2}{|c|}{$\operatorname{Van}(\mu \mathbf{g} / \mathbf{m L})$} \\
\hline & 2.5 & 5 & 7.5 & 30 & MIC & MBC & MIC & МBC \\
\hline SA-27 & $6.8 \pm 0.0$ & $8.5 \pm 0.4$ & $9.41 \pm 0.8$ & $19.3 \pm 0.03$ & $0.125 \pm 0.0$ & $0.125 \pm 0.0$ & 0.5 & 1 \\
\hline SA-4 & $7.26 \pm 0.8$ & $8.6 \pm 0.3$ & $9.3 \pm 0.46$ & $19.1 \pm 0$ & $0.125 \pm 0.0$ & $0.25 \pm 0.0$ & 1 & 2 \\
\hline SA-A & $7.63 \pm 0.7$ & $7.75 \pm 0.9$ & $9.1 \pm 0.5$ & $18.6 \pm 0.1$ & $0.25 \pm 0.0$ & $8.0 \pm 0.0$ & 0.5 & 1 \\
\hline SA-3 & $6.8 \pm 0.0$ & $10.2 \pm 0.4$ & $10.6 \pm 0.4$ & $20.2 \pm 0.3$ & $0.06 \pm 0.0$ & $0.125 \pm 0.0$ & 0.25 & 0.5 \\
\hline SA-K & $6.8 \pm 0.0$ & $7.6 \pm 0.7$ & $8.52 \pm 0.14$ & $16.5 \pm 0.01$ & $0.125 \pm 0.0$ & $0.25 \pm 0.0$ & 0.5 & 0.5 \\
\hline SA-6 & $6.8 \pm 0.0$ & $8.6 \pm 0.6$ & $8.97 \pm 0.5$ & $21.2 \pm 0.14$ & $0.05 \pm 0.0$ & $1.0 \pm 0.0$ & 1 & 2 \\
\hline SA-25 & $6.8 \pm 0.0$ & $7.8 \pm 0.9$ & $9.02 \pm 0.1$ & $20.8 \pm 0.09$ & $0.125 \pm 0.0$ & $0.125 \pm 0.0$ & 0.25 & 1 \\
\hline SA-33 & $6.8 \pm 0.0$ & $9.4 \pm 0.3$ & $9.93 \pm 0.4$ & $19.8 \pm 0.28$ & $0.06 \pm 0.0$ & $0.125 \pm 0.1$ & 0.5 & 1 \\
\hline SA-32 & $8.3 \pm 0.2$ & $8.7 \pm 0.3$ & $8.92 \pm 0.3$ & $19.2 \pm 0.42$ & $0.125 \pm 0.0$ & $0.33 \pm 0.14$ & 0.5 & 1 \\
\hline SA-34 & $6.8 \pm 0.0$ & $9.1 \pm 0.23$ & $9.67 \pm 0.4$ & $21.0 \pm 0.6$ & $0.082 \pm 0.04$ & $0.33 \pm 0.14$ & 0.5 & 1 \\
\hline SA-26 & $6.8 \pm 0.0$ & $7.8 \pm 0.87$ & $8.98 \pm 0.3$ & $20.4 \pm 0.37$ & $0.21 \pm 0.07$ & $0.33 \pm 0.14$ & 1 & 1 \\
\hline Means & $7.1 \pm 0.3$ & $8.6 \pm 0.27$ & $9.3 \pm 0.19$ & $19.6 \pm 0.19$ & $0.162 \pm 0.02$ & $0.31 \pm 0.06$ & $0.58 \pm 0.27$ & $1.04 \pm 0.49$ \\
\hline
\end{tabular}

Abbreviations: MBC, minimal bactericidal concentration; MIC, minimal inhibitory concentration; SA, S. aureus.

\section{References}

1. Parsa A. Medicinal plants and drugs of plant origin in Iran. I. Qual Plant Mater Veg. 1959;5(4):375-94. doi: 10.1007/bf01099755.

2. Flanagan J, Meyer M, Pasamar MA, Ibarra A, Roller M, Alvarez i Genoher $\mathrm{N}$, et al. Safety evaluation and nutritional composition of a Fraxinus excelsior seed extract, FraxiPure. Food Chem Toxicol. 2013;53:10-7. doi: 10.1016/j.fct.2012.11.030. [PubMed: 23201448].

3. Kostova I, Iossifova T. Chemical components of Fraxinus species. Fitoterapia. 2007;78(2):85-106. doi: 10.1016/j.fitote.2006.08.002. [PubMed: 17184933].

4. Naimie H. Attempts to isolate and purify substances inhibitory to Bacillus subtilis from tree bark. Angew Bot. 1964;38:1-43.

5. Martin JT, Baker EA, Byrde RJW. The fungitoxicities of plant furocoumarins. Ann Appl Biol. 1966;57(3):501-8. doi: 10.1111/j.17447348.1966.tb03842.x.

6. Middleton P, Stewart F, Al-Qahtani S, Egan P, O'Rourke C, Abdulrahman A. Antioxidant, antibacterial activities and general toxicity of Alnus glutinosa, Fraxinus excelsior and Papaver rhoeas. Iran JPharm Res. 2010;4(2):101-3.

7. el-Ghazaly M, Khayyal MT, Okpanyi SN, Arens-Corell M. Study of the anti-inflammatory activity of Populus tremula, Solidago virgaurea and Fraxinus excelsior. Arzneimittelforschung. 1992;42(3):333-6. [PubMed: 1497695].
8. López-Carreras N, Fernández-Vallinas S, Hernández R, Miguel M, Aleixandre A. Short-term effect of an aqueous Fraxinus excelsior L. seed extract in spontaneously hypertensive rats. Food Res Int. 2013;53(1):81-7. doi: 10.1016/j.foodres.2013.03.050.

9. Okpanyi SN, Schirpke-von Paczensky R, Dickson D. [Antiinflammatory, analgesic and antipyretic effect of various plant extracts and their combinations in an animal model]. Arzneimittelforschung. 1989;39(6):698-703. German. [PubMed: 2476136].

10. Maghrani M, Zeggwagh NA, Lemhadri A, El Amraoui M, Michel JB, Eddouks M. Study of the hypoglycaemic activity of Fraxinus excelsior and Silybum marianum in an animal model of type 1 diabetes mellitus. J Ethnopharmacol. 2004;91(2-3):309-16. doi: 10.1016/j.jep.2004.01.008. [PubMed: 15120454].

11. Visen P, Saraswat B, Visen A, Roller M, Bily A, Mermet C, et al. Acute effects of Fraxinus excelsior L. seed extract on postprandial glycemia and insulin secretion on healthy volunteers. J Ethnopharmacol. 2009;126(2):226-32. doi: 10.1016/j.jep.2009.08.039. [PubMed: 19723572].

12. Ibarra A, Bai N, He K, Bily A, Cases J, Roller M, et al. Fraxinus excelsior seed extract FraxiPure limits weight gains and hyperglycemia in high-fat diet-induced obese mice. Phytomedicine. 2011;18(6):479-85. doi: 10.1016/j.phymed.2010.09.010. [PubMed: 21036576].

13. Adams RP. Identification of essential oil components by gas chromatography/quadrupole mass spectroscopy. Allured Pub. Corporation; 2001. 
14. Mahboubi M, Haghi G. Antimicrobial activity and chemical composition of Mentha pulegium L. essential oil. J Ethnopharmacol. 2008;119(2):325-7. doi: 10.1016/j.jep.2008.07.023. [PubMed: 18703127].

15. Sieniawska E, Światek Ł, Rajtar B, Kozioł E, Polz-Dacewicz M, Skalicka-Woźniak K. Carrot seed essential oil-Source of carotol and cytotoxicity study. Ind Crop Prod. 2016;92:109-15. doi: 10.1016/j.indcrop.2016.08.001.

16. Jasicka-Misiak I, Lipok J, Nowakowska EM, Wieczorek PP, Mlynarz P, Kafarski P. Antifungal activity of the carrot seed oil and its major sesquiterpene compounds. Z Naturforsch C. 2004;59(11-12):791-6. [PubMed: 15666536].
17. Staniszewska M, Kula J, Wieczorkiewicz M, Kusewicz D. Essential oils of wild and cultivated carrots-the chemical composition and antimicrobial activity. J Essent Oil Res. 2005;17(5):579-83. doi: 10.1080/10412905.2005.9699002.

18. Selestino Neta MC, Vittorazzi C, Guimaraes AC, Martins JD, Fronza M, Endringer DC, et al. Effects of beta-caryophyllene and Murraya paniculata essential oil in the murine hepatoma cells and in the bacteria and fungi 24-h time-kill curve studies. Pharm Biol. 2017;55(1):1907. doi: 10.1080/13880209.2016.1254251. [PubMed: 27927082]. [PubMed Central: PMC6130565]. 